\title{
Review of the salinity optima of the diatom Staurosirella pinnata: implications for water reform in Australia
}

\author{
J. Marohasy \& J. Abbot \\ School of Medical and Applied Sciences, \\ Central Queensland University, Noosa, Australia
}

\begin{abstract}
Water policy reform in Australia has been driven by a requirement to increase freshwater flows to Lake Alexandrina, part of a terminal near-coastal system at the end of Australia's longest river, the Murray. This water policy is based on the lake's listing in 1985 under The Convention on Wetlands of International Importance as freshwater, and analysis of a limited number of diatoms from one sediment core. The analysis classified Staurosirella pinnata, the dominant diatom species, as a freshwater species. However, a review of the literature suggests $S$. pinnata has a very broad salinity tolerance, and a recent study in an adjacent coastal lagoon, the Coorong, indicates $S$. pinnata has a salinity optimum of $29 \mathrm{ppt}$. If the natural state of Lake Alexandrina is estuarine, rather than freshwater, then water policy could focus on restoring connectivity with the Southern Ocean through removal of the barrages built in the 1930s to stop salt water intrusions, rather than increased freshwater flows from the Murray River.

Keywords: diatom, water reform, Staurosirella pinnata, Murray River, barrages.
\end{abstract}

\section{Introduction}

A key objective of water reform in Australia is the redistribution of water from irrigated agriculture back to the environment by way of increased environmental flows. This became a priority following the Millennium drought (2001 to 2009) that resulted in water levels receding at Lake Alexandrina, which is a vast and shallow terminal lake at the end of the Murray and Darling river-systems in southeastern Australia, Figure 1. 


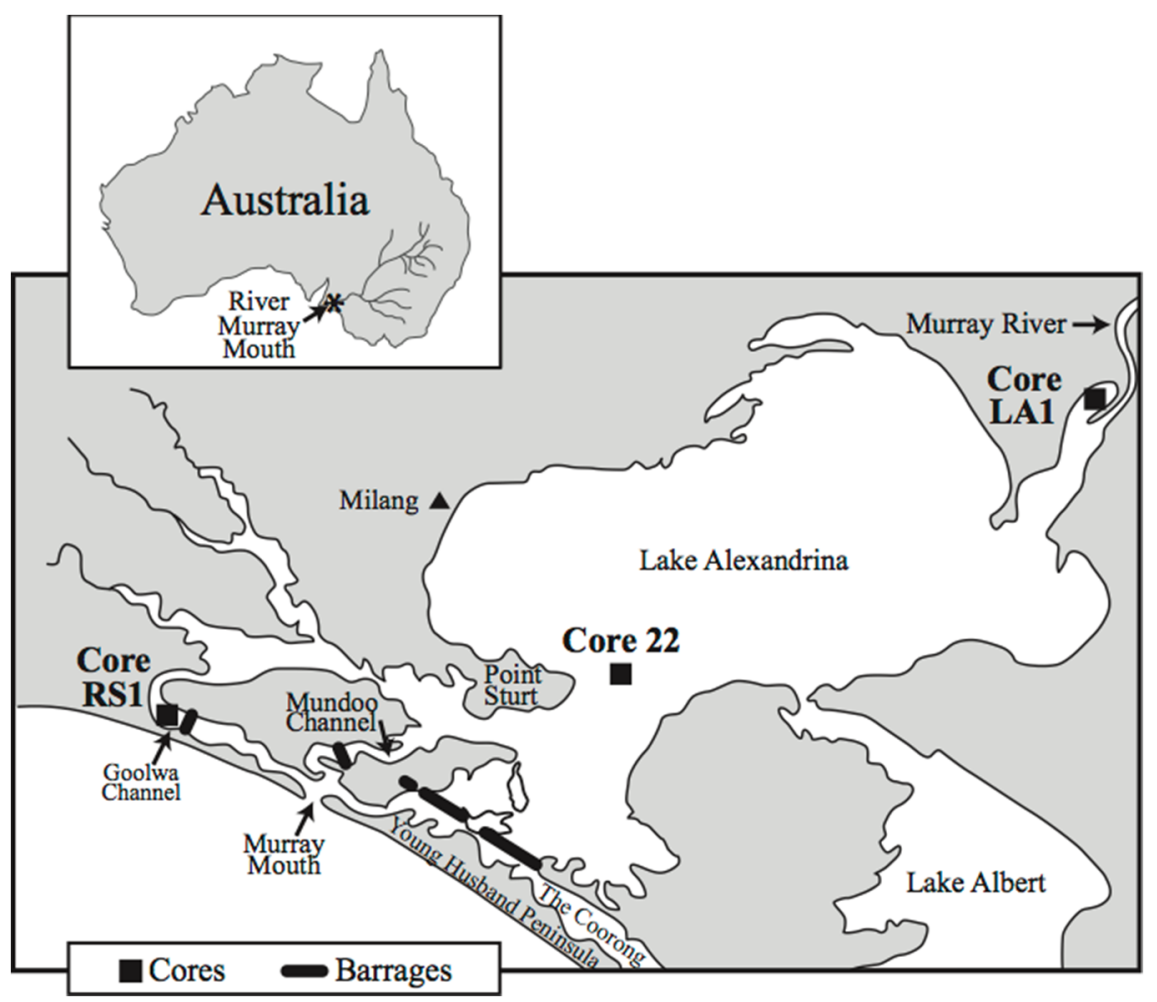

Figure 1: Lake Alexandrina is situated at the end of the Murray-Darling River system in south eastern Australia and was once connected to the Southern Ocean by a series of channels that are now blocked by barrages. The Coorong is a narrow body of water to the south east of Lake Alexandrina separated from the Southern Ocean by the Young Husband Peninsula.

A plan for the Murray Darling Basin, legislated in November 2012 under the Commonwealth Water Act 2007, will limit the quantity of water in the Basin that can be used for irrigated agriculture and result in the buyback of about one third of all the water previously used to produce food in non-drought years. An objective of this redistribution of water from agriculture to the environment is to give effect to The Convention on Wetlands of International Importance (The Ramsar Convention) [1]. This Ramsar Convention is an intergovernmental treaty that provides the framework for national action and international cooperation for the conservation and wise use of wetlands and their resources.

In 1985, Lake Alexandrina became listed under the Ramsar Convention as a freshwater lake. The Australian government reporting to the Secretary General of the Ramsar Convention in Switzerland has stated that the key issue is a lack of adequate freshwater flowing into the lake from the Murray River (e.g. report with letter from C. Zammit, 13 December 2006). However, Lake Alexandrina is 
considered by many $[2,3]$ to have been in ecological decline since construction of sea dykes, known locally as barrages, across the channels that once connected the lake to the Southern Ocean, Figure 1. The barrages were constructed in the 1930s to stop salt water intrusions. Bourman et al. [3] states: "Originally a vibrant, highly productive estuarine ecosystem of 75,000 ha, characterized by mixing of brackish and fresh water with highly variable flows, barrage construction has transformed the lakes into freshwater bodies with permanently raised water levels".

The Murray Darling Basin Authority, MDBA, and the South Australian Department of Environment, Water and Natural Resources are jointly responsible for management of Lake Alexandrina. These government agencies claim that analysis of diatoms in lakebed sediments shows that Lake Alexandrina has been predominantly freshwater for 7,000 years, and that this is therefore its natural ecological character $[4,5]$.

Diatoms are unicellular algae with ornate cell walls made of silica. As different species of diatom usually have different salinity tolerances, and preserve well in sediment, diatoms are often used in paleoliminology studies as indicators of past salinity. Reports to government [6], and published papers [7] that claim Lake Alexandrina has a 7,000-year freshwater history, rely on the qualitative assessment of the diatoms from a single sediment core taken from Lake Alexandrina in 1989 from a water depth of $3.7 \mathrm{~m}$ just to the northwest of Port Sturt, (Figure 1). This sediment core, measuring $8 \mathrm{~cm}$ in diameter and $494 \mathrm{~cm}$ in length, was first examined for diatoms by D.A. Penny as a contribution to a $\mathrm{PhD}$ study into the sedimentology of Lake Alexandrina by Barnett [8]. The study by Penny, detailed in Barnett [8], remains the most comprehensive investigation of the diatoms of Lake Alexandrina. Penny identified 113 species from Core 22 and Barnett $[8,9]$ stated that this core represented an approximate 7,000-year lower Murray history. Subsequent diatom studies refer to a subset of this original study, examining as few as 15 of the original 113 diatom species $[6,7]$.

Barnett [8,9] and Fluin et al. [6, 7] make determinations about past salinities in Lake Alexandrina based on a qualitative assessment of the salinity tolerance of the diatom species found in Core 22, but without any explanation of how the diatoms were categorized with respect to salinity. For example, Fluin et al. $[6,7]$ concluded that over the 7,000-year record there are minimal numbers (generally $<10$ percent) of estuarine diatoms with Thalassiosira lacustris (Grunow) Hasle being the most numerous estuarine-indicator. Fluin et al. [7] also concluded that there is no evidence, based on the diatom species preserved in Core 22, for substantial marine incursions into Lake Alexandrina. However, it is unclear how Fluin et al. $[6,7]$ assigned diatom species to the categories of freshwater, estuarine and marine. They classify the dominant diatom species at almost all depths in all sediment cores, Staurosirella pinnata (Ehrenberg) (Williams and Round [10]), as freshwater.

The most recent government-commissioned report 'An Environmental History of the Lower Lakes and Coorong' [7] gives the impression that three new cores have been taken from Lake Alexandrina, but this is not the case. This report [7] is again based on Core 22 (relabeled LA2), and an additional core, LA1, that was collected in 1996 from the extreme north of Lake Alexandrina, behind the inlet of 
the Murray River, Figure 1. Analysis of the diatom fauna from LA1 has proved to be problematic, as detailed in Fluin et al. [6]. In particular, the core is only $85 \mathrm{~cm}$ in length with the top 6-7 cm being considered an "outlier" and the lower sections (40 to $85 \mathrm{~cm}$ ) all yielding carbon dates as of "similar age" calibrated to 7,400 to 7,600 years BP. The third core, RS1, discussed in Fluin et al. [7], is acknowledged to contain predominantly marine diatom species and is not from Lake Alexandrina but rather the Goolwa channel situated immediately behind the Murray's sea mouth, Figure 1.

In this study, data from the original analysis of Core 22 is reanalysed confirming that $S$. pinnata is the dominant diatom species, and then the literature reviewed to establish the salinity range and optima of $S$. pinnata.

\section{Review of data and literature}

Barnett's $\mathrm{PhD}$ thesis [8] contains detailed information on the diatoms found in Core 22, which is the only sediment core taken from Lake Alexandrina proper that has ever been successfully analysed for diatoms. Appendix IV of the thesis contains a list of 113 species and their percentage abundance at depths of $1,4,8$, $20,40,60,80,100,120,160,180,220,260,300,340,380,411,420,460$ and 490 $\mathrm{cm}$. Carbon radiometric dating was used by Barnett $[8,9]$ to determine the chronology of the core, with the middle section $(220-300 \mathrm{~cm})$ corresponding to an age of 2,300 years before present, and the 460-490 $\mathrm{cm}$ section corresponding to 7,000 years before present [9].

Considering the 14 most common diatom species listed in Appendix IV, and defined here as species that occur as $\geq 5$ percent of the total at any one depth, Fragilaria pinnata is overwhelmingly dominant at almost all depth, Figure 2. A revision of the genus Fragilaria [10] saw the species $F$. pinnata made synonymous with, and to be superseded by, Staurosirella pinnata (Ehrenberg) Williams \& Round. F. pinnata will thus henceforth be referred to as S. pinnata.

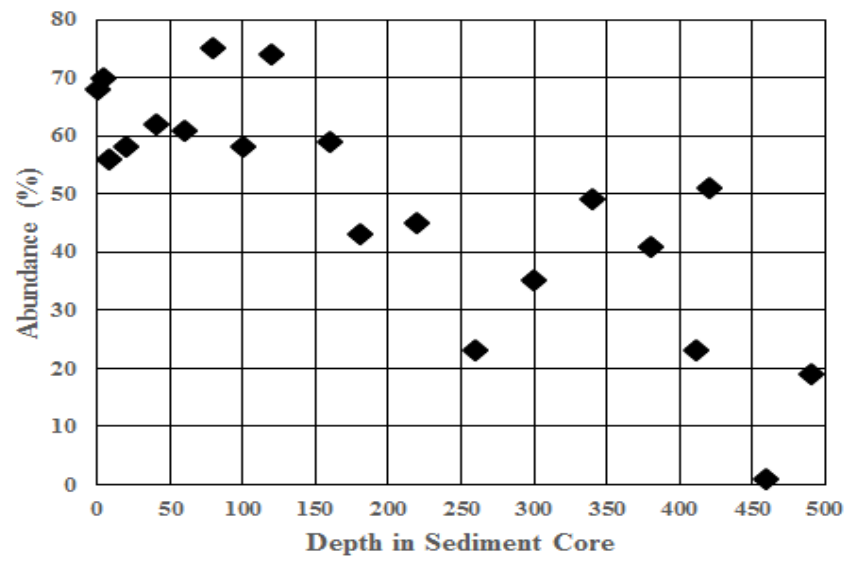

Figure 2: Percentage abundance of Staurosirella pinnata at each depth in Core 22 after Barnett 1993. 
This species is particularly dominant at depths less than or equal to $220 \mathrm{~cm}$ where it comprises 45 percent or more of the diatom flora, Figure 2 . Only at 460 $\mathrm{cm}$ is the species rare, comprising only 1 percent of the diatom flora, Figure 2. At this depth there is no single dominant species with Thalassiosira lacustris, Navicula cincta and Nitzschia pusilla the most abundant species but only comprising 12, 8 and 6 percent of the diatom flora respectively (Appendix IV, Barnett 1993). Considering the common diatom species except $S$. pinnata (i.e. excluding $S$. pinnata from the analysis), mean percentage abundance at the different depth various between 1.9 and 4.6 percent: that is no species dominants at any depth. A maximum percentage abundance of 24 and 23 percent, respectively, is recorded for Fragilaria parasitica at the top of the sediment core at the depths of 0 and $4 \mathrm{~cm}$ but this species is relatively rare at most other depths.

$S$. pinnata is listed in influential international reference works as a freshwater diatom [11-13]. This classification of freshwater is consistent with Barnett [9] where the species is described as oligohalibous to lower mesohalobous [9]. Oligohalibous refers to freshwater species, typically with a salinity range less than 2 parts per thousand (ppt). A mesohalobous species will typically tolerate a salinity range from 0.2 to $30 \mathrm{ppt}$ with the lower mesohalobous species associated with "lower" brackish conditions typically defined as less than $10 \mathrm{ppt}$ [11].

Barnett [9] while acknowledging a marine origin for the lake, states that the dominance of $S$. pinnata since 6,000 years before present, suggests "a greater freshwater influence" for most of the history of Lake Alexandrina. Fluin et al. [6] state that the presence of $S$. pinnata is indicative of a "meso-eutrophic reed fringed environment with fresh to brackish water in a $\mathrm{pH}$ range of 8.0-9.0" but without citing a reference. Fluin et al. [6] cite Gell [14] later in that paper with reference to the salinity tolerance of $S$. pinnata relative to other diatom species. Gell [14] in their study of diatoms in wetlands upstream of Lake Alexandrina, place $S$. pinnata in a Group 6, which has a designated salinity of more than $5 \mathrm{ppt}$, yet later in the same paper Gell [14] indicate that $S$. pinnata has a salinity optimum of $0.59 \mathrm{ppt}$. Meanwhile, Gell et al. [15] suggests a salinity optimum of 0.84 to $35.63 \mathrm{ppt}$ for $S$. pinnata, Table 1 .

This broader range of $0.84-35.63 \mathrm{ppt}$ is similar to that reported by Saunders et al. [16] of 1.5-43.4 ppt based on 34 sampling sites in 19 lagoons along the east coast of Tasmania, south eastern Australia. Saunders et al. [16] used this data to determine that $S$. pinnata had a summer salinity optima of $9.5 \mathrm{ppt}$ and a winter optima of $12.1 \mathrm{ppt}$, Table 1. Quantitative studies similar to Saunders et al. [16], based on comprehensive sampling regimes in estuaries in China and Argentina, have found that $S$. pinnata has optima of $6.34 \mathrm{ppt}$ and $17.3 \mathrm{ppt}$, respectively [1719], Table 1.

In the Coorong, a coastal lagoon adjacent to Lake Alexandrina, Figure 1, S. pinnata dominated during a period from 1997 to 2002 when average salinity was 35 ppt [20]. Based on a salinity transfer model developed for the Coorong, the salinity optima for this species is 29 ppt [20].

This very high salinity optima, close to seawater, is consistent with Finkel et al. [21] description of $S$. pinnata as a marine, chain-forming pennate species. 
Table 1: Summary of the ecological characteristics of Staurosirella pinnata based on previous literatures. Salinity is measured in parts per thousand, ppt. When the ppt value has been derived from a weighted average optimum, or tolerances it is designated by WA Opt \& WA Tol, respectively. Brackets designate salinity inferred from habitat and/or locality.

\begin{tabular}{|c|c|c|c|}
\hline $\begin{array}{c}\text { Salinity } \\
\text { (ppt) }\end{array}$ & Environment & Locations & Authors \\
\hline$(>25)$ & Estuary & $\begin{array}{c}\text { Baker Bay, Columbia } \\
\text { River, USA } \\
\end{array}$ & $\begin{array}{c}\text { McIntire \& } \\
\text { Amspoker } 1984\end{array}$ \\
\hline \multirow[t]{4}{*}{$(>25)$} & Estuary & $\begin{array}{c}\text { Youngs Bay, Columbia } \\
\text { River } \\
\end{array}$ & $\begin{array}{c}\text { McIntire \& } \\
\text { Amspoker } 1984 \\
\end{array}$ \\
\hline & Tidal mud flats & Mar Chiquita, Argentina & Espinosa et al. 2006 \\
\hline & Estuary & Itupanema Beach, Brazil & Ribeiro et al. 2010 \\
\hline & $\begin{array}{l}\text { No coastal } \\
\text { records, found } \\
\text { inland creeks } \\
\text { and rivers }\end{array}$ & Queensland, NSW, Victoria & Foged 1978 \\
\hline$(33-40)$ & $\begin{array}{l}\text { Mangrove forest } \\
\text { in coastal } \\
\text { lagoon }\end{array}$ & Bahia Magdalena, Mexico & Fuerte et al. 2010 \\
\hline $0.21-2.34$ & Wetland & $\begin{array}{l}\text { Hattah Lake, Murray } \\
\text { Darling, Australia }\end{array}$ & Gell et al. 2002 \\
\hline $0.84-35.63$ & Wetland & $\begin{array}{c}\text { Psyche Bend, Murray } \\
\text { Darling } \\
\end{array}$ & Gell et al. 2002 \\
\hline $0.66-21.43$ & Estuary & $\begin{array}{c}\text { Quequen Grande River, } \\
\text { Argentina } \\
\end{array}$ & Hassan et al. 2006 \\
\hline $1.05-25.2$ & Estuary & Mar Chiquita, Argentina & Hassan et al. 2006 \\
\hline $\begin{array}{c}6.34 \\
\text { WA Opt }\end{array}$ & Estuaries & Buenos Aires province & Hassan et al. 2009 \\
\hline $\begin{array}{c}6.42 \\
\text { WA Tol } \\
\end{array}$ & Estuaries & Buenos Aires province & Hassan et al. 2009 \\
\hline 150 & Saline lake & Mono Lake, California & $\begin{array}{c}\text { Herbst \& Blinn } \\
1998 \\
\end{array}$ \\
\hline \multirow[t]{2}{*}{38} & Tidal estuary & Chesapeake Bay, USA & Marshall et al. 2005 \\
\hline & Intertidal marsh & $\begin{array}{c}\text { Masonboro Island, North } \\
\text { Carolina }\end{array}$ & McGee 2005 \\
\hline $\begin{array}{l}9.5-12.2 \\
\text { WA Opt }\end{array}$ & Coastal lagoons & Tasmania, Australia & Saunders et al. 2007 \\
\hline \multirow[t]{2}{*}{$\begin{array}{l}1.5-43.4 \\
\text { WA Tol } \\
\end{array}$} & Coastal lagoons & Tasmania & Saunders et al. 2007 \\
\hline & $\begin{array}{l}\text { Estuaries and } \\
\text { coastal lakes }\end{array}$ & South East Australia & Saunders 2011 \\
\hline \multirow[t]{2}{*}{$42-65$} & $\begin{array}{c}\text { Hypersaline } \\
\text { coastal lagoon }\end{array}$ & Arauama Lake, Brazil & Sylvestre et al. 2001 \\
\hline & Estuary & Pearl River, China & Zong et al. 2010 \\
\hline
\end{tabular}


Table 1 Continued.

\begin{tabular}{|c|c|c|c|}
\hline $\begin{array}{c}\text { Salinity } \\
\text { (ppt) }\end{array}$ & Environment & Locations & Authors \\
\hline$(35)$ & Coastal waters & British coast & Hendey 1964 \\
\hline \multirow[t]{3}{*}{$(35)$} & Open ocean & $\begin{array}{l}\text { Sargasso Sea, North } \\
\text { Atlantic, USA }\end{array}$ & Finkel et al. 2010 \\
\hline & Brackish water & $\begin{array}{c}\text { Oyster Pond, Martha's } \\
\text { Vineyard, USA }\end{array}$ & Finkel et al. 2010 \\
\hline & Ocean & $\begin{array}{c}\text { Provasoli-Guillard National } \\
\text { Center for the Culture of } \\
\text { Marine Phytoplankton }\end{array}$ & Finkel et al. 2010 \\
\hline $\begin{array}{c}0.25 \\
\text { WA Opt } \\
\end{array}$ & Lakes & British Columbia, Canada & Wilson et al. 1996 \\
\hline $\begin{array}{c}0.01-4.84 \\
\text { WA Tol }\end{array}$ & Lakes & British Columbia & Wilson et al. 1996 \\
\hline $\begin{array}{c}29 \\
\text { WA Opt }\end{array}$ & Coastal lagoon & Coorong, South Australia & Haynes et al. 2011 \\
\hline
\end{tabular}

Similarly, Hendey [22] described the species as common along the British coastline. S. pinnata also been found at Itupanema Beach, Brazil [23] and tidal estuaries and marshes in North America [24-27]. S. pinnata has been found in hypersaline coastal lagoon in Brazil [28] and California [29] and in a mangrove forests in Mexico [30] and tidal mudflat in Argentina [31], Table 1. In contrast, Foged [32] only found the species in land creeks and rivers in eastern Australia, while Wilson et al. [33] report the species as present in the freshwater lakes of British Columbia.

What could be considered inconsistent classifications concerning salinity ranges, that is the freshwater [11-13] versus the salt water listings [26-28], suggest either $S$. pinnata has an exceptionally broad salinity tolerance, or that there is taxonomic confusion. Indeed the taxon could be represented by a speciescomplex. Some samples collected from North America exhibit several morphological variants that are often included under the name S. pinnata [34].

\section{Discussion}

Five barrages block the channels that converge on the Murray River's sea mouth preventing salt water intrusions. It is argued that these barrages are necessary because the growth of upstream irrigation industry during the $20^{\text {th }}$ century reduced river flows which previously maintained a freshwater environment in Lake Alexandrina for most of its 7,000 year history. The diatoms preserved in the lake's sediment are routinely cited as supporting evidence [4-7]. There has been no discussion, or acknowledgement, however, in this government-sponsored literature concerned with this water policy reform of discrepancies and inconsistencies in the characterisation of $S$. pinnata, or the limited data on which 
this freshwater determination has been made, in particular that it is based on a single sediment core.

Generally determinations of historical salinity are based on many more samples, followed by the construction of diatom-salinity inference models. Zong et al. [19], for example, created a transfer function based on 77 modern surface sediment samples taken from across the Pearl River estuary in China to quantitatively establish the salinity optima of the modern diatom assemblages. A training set was then used to reconstruct paleo-salinities for four sediment cores that correspond to the past 9,000 years of record for the Pearl River estuary. Hassan et al. [18] used a similar methodology to reconstruct changes in salinity along the northeastern coast of Argentina, developing the training set from sampling at 40 sites in three different estuaries. At the Orielton Lagoon in southeast Tasmania, Australia, there is no natural salinity gradient because of the construction of a causeway, so Saunders et al. [16] sampled 19 lagoons around the Tasmanian east coast to develop a training set which could then be applied to reconstruct the history of Orielton lagoon.

A comprehensive review of the literature, Table 1, shows that $S$. pinnata has been characterised as both a freshwater and also marine species, Table 1. This could be indicative of a confused taxonomy. However, where detailed quantitative ecological studies have been undertake, for example in the Coorong, Tasmania, Argentina and China $[16,17,19,20]$, the species is unambiguously estuarine. This would also be consistent with geomorphological studies of Lake Alexandrina, which suggest it was originally the central basin of a wave-dominated estuary [35, $36]$ before construction of the barrages in the 1930s [2, 3].

The political implications are significant with the freshwater classification of Lake Alexandrina driving the redistribution of water allocations in the Murray Darling Basin, and assisting the allocation of more than US\$10 billion dollars of government funding to different interest groups since 2009 [37]. However, if the natural environment of Lake Alexandrina is estuarine, and the objective of the water reform restoration of natural environments, then the policy would be very different. In particular, it might be focused on reconnecting Lake Alexandrina with the Southern Ocean to facilitate the inflow of salt water [38].

\section{Acknowledgement}

This research was funded by the B. Macfie Family Foundation that has no financial interests in the Murray Darling or Lake Alexandrina.

\section{References}

[1] Kildea, P., \& Williams, G., The Water Act and the Murray-Darling Basin Plan. The Public Law Review 22, pp. 9-14, 2011.

[2] Jensen, A., M., Good, P., Tucker \& Long, M. River Murray Barrages Environmental Flows: An Evaluation of Environmental Flow Needs in the Lower Lakes and Coorong. A report for the Murray-Darling Basin 
Commission, Department of Environment, Heritage and Aboriginal Affairs, Government of South Australia, Adelaide, 2000.

[3] Bourman, R.P., C.V. Murray-Wallace, A.P. Belperio \& N. Harvey, Rapid coastal geomorphic change in the River Murray Estuary of Australia. Marine Geology 170, pp. 141-168, 2000.

[4] MDBA, Fact Sheet: All about the barrages, 2012, http://www.mdba.gov.au/sites/default/files/pubs/FS_barrages.pdf

[5] Government of South Australia, Securing the Future: A Long-term plan for the Coorong, Lower Lakes and Murray Mouth, Adelaide, 2012, http://www.murrayfutures.sa.gov.au/images/file_groups/217/securing the future_web.pdf

[6] Fluin, J., Gell, P., Haynes, D., Tibby, J. \& Hancock, G., Palaeolimnological evidence for the independent evolution of neighboring terminal lakes, the Murray Darling Basin, Australia. Hydrobiologia 591, pp. 117-134, 2007.

[7] Fluin, J., Haynes, D. \& Tibby, J, An Environmental History of the Lower Lakes and Coorong. Report Commissioned by the South Australian Department of Environment and Heritage, Adelaide, 2009.

[8] Barnett, E.J., Recent sedimentary history of Lake Alexandrina and the Murray Estuary. PhD Thesis, School of Earth Sciences, The Flinders University of South Australia, Adelaide, 1993.

[9] Barnett, E.J., A Holocene paleoenvironmental history of Lake Alexandrina, South Australia. Journal of Paleolimnology 12, pp. 259-268, 1994.

[10] Williams, D.M. \& Round, F.E., Revision of the genus Fragilaria. Diatom Research, 2, pp. 267-288, 1988.

[11] Hustedt, F., Die Diatomeenflora des Fluss-systems der Weser im Gebiet der Hansestadt Bremen. Abh. Naturw. Ver. Bremen, 34(3), pp. 181-440, 1957.

[12] Patrick, R. \& Reimer, C.W., The diatoms of the United States, exclusive of Alaska and Hawaii, Volume 1-Fragilariaceae, Eunotiaceae, Achnanthaceae, Naviculaceae. Academy of Natural Sciences of Philadelphia Monograph No. 13, p. 688, 1966.

[13] Lange-Bertalot, H. \& Simonsen, R., A Taxonomic Revision of the Nitzschiae lanceolatae Grunow. 2. European and Related Extra-European Freshwater and Brackish Water Taxa. Bacillaria, 1, pp. 11-112, 1978.

[14] Gell, P.A., The Development of a Diatom Database for Inferring Lake Salinity, Western Victoria, Australia: Towards a Quantitative Approach for Reconstructing Past Climates, Australian Journal of Botany,45, pp. 389423, 1997.

[15] Gell. P.A., I.R. Sluiter \& Fluin, J., Seasonal and interannual variations in diatom assemblages in Murray River connected wetlands in north-west Victoria, Australia. Marine and Freshwater Research, 53, pp. 981-992, 2002.

[16] Saunders, K.M., A. McMinn, D. Roberts, D.A. Hodgson \& Heijnis, H., Recent human-induced salinity changes in Ramsar-listed Orielton Lagoon, south-east Tasmania, Australia: a new approach for coastal lagoon conservation and management. Aquatic Conservation: Marine and Freshwater Ecosystems, 17, pp. 51-70, 2007. 
[17] Hassan, G.S. \& M.A. Espinosa \& Isla, E.F., Modern diatom assemblages in surface sediments from estuarine systems in the southeastern Buenos Aires Provinces, Argentina. Journal of Paleolimnology, 35, pp. 39-53, 2006.

[18] Hassan, G.S., M.A. Espinosa. \& Isla, E. F., Diatom-based inference model for paleosalinity reconstructions in estuaries along the northeastern coast of Argentina. Paleogeography, Paleoclimatology. Paleoecology, 275, pp. 7791, 2009.

[19] Zong, Y, A.C. Kemp, F. Yu, J.M. Lloyd, G. Huang \& W.W.S. Yim, 2010. Diatoms from the Pearl River estuary, China and their suitability as water salinity indicators for coastal environments. Marine Micropaleontology, 75, pp. 38-49, 2010.

[20] Haynes, D., R. Skinner, J. Tibby, J. Cann \& J. Fluin, Diatom and foraminifera relationships to water quality in the Coorong, South Australia, and the development of a diatom-based salinity transfer function. Journal of Paleolimnology, 46, pp. 543-560, 2011.

[21] Finkel, Z.V., Matheson, K.A., Regan, K.S. \& Irwin, A.J. Geotypic and phenotypic variation in diatom silicification under paleo-oceanographic conditions. Geobiology, 8, pp. 433-445, 2010.

[22] Hendey, N.I. An Introductory Account of the Smaller Algae of British Coastal Waters. Part V. Bacillariophyceae (Diatoms). Otto Koeltz Science Publishers, Berlin. p. 317, 1964.

[23] Ribeiro, F.C.P., De Senna, C.D.S.R., \& Torgan, L.C., The use of diatoms for paleohydrological and paleoenvironmental reconstructions of Itupanema Beach, Para State, Amazon Region, during the last millennium. Revista Brasileira de Paleontologia, 13, pp. 21-32, 2010.

[24] Marshall, H.G., Alden, R.W., A comparison of phytoplankton assemblages in the Chesapeake and Delaware estuaries (USA), with emphasis on diatoms Hydrobiologia, 269/270, pp. 251-261, 1993.

[25] Marshall, H.G., L. Burchardt \& Lacouture, R. A review of phytoplankton composition within Chesapeake Bay and its tidal estuaries. Journal of Plankton Research, 27, pp. 1083-1102, 2005.

[26] McIntire, C.D. \& Amspoker, C.M., Benthic Primary Production in the Columbia River Estuary, Columbia River Estuary Data Development Program, Oregon State University, Corvallis, 1984.

[27] McGee, D.K., Morphological comparisons of shallow and deepwater benthic marine diatoms of Onslow Bay, North Carolina, Masters of Science Thesis, Department of Earth Sciences, University of North Carolina, Wilmington, 2005.

[28] Sylvestre, F., B. Beck-Eichler, W. Duleb, \& Debenay, J., Modern benthic diatom distribution in a hypersaline coastal lagoon: the Lagoa de Araruama, Brazil. Hydrobiologia 443, pp. 213-231, 2001.

[29] Herbst, D.B. \& D.W. Blinn, Experimental mesocosm studies of salinity effects on the benthic algal community of a saline lake. Journal of Phycology, 34, pp. 772-778, 1998. 
[30] Fuerte, F.O, D.A. Beltrones \& J.N. Navarro, Benthic diatoms associated with mangrove environments in the northwest region of Mexico, Conabio: Tlalpan. p. 206, 2010.

[31] Espinosa, M.A., G.S. Hassan \& Isla, F.I., Diatom distribution across a temperate microtidal marsh, Mar Chiquita coastal lagoon, Argentina. Thalassa, 22, pp. 9-16, 2006.

[32] Foged, N., Diatoms in Eastern Australia. Bibliotheca Phycologica, Band 41. Strauss \& Cramer, Hirschberg. p. 243, 1978.

[33] Wilson, S.E., B.F. Cumming \& J.P. Smol, Assessing the reliability of salinity inference models from diatom assemblages: an examination of a 219-lake data set from western North America. Canadian Journal of Fisheries and Aquatic Science 53, pp. 1580-1594, 1996.

[34] US Geological Survey, Identification guide and ecological resource for diatoms of the United States http://westerndiatoms.colorado.edu/taxa/ species/staurosirella_pinnata

[35] Roy, P.S., New South Wales Estuaries: Their Origin and Evolution. Coastal Geomorphology in Australia, eds. B. G. Thom. Academic Press, Sydney. pp. 99-121, 1984.

[36] Ryan, D.A., Heap, A.D., Radke L., \& Heggie, D.T., Conceptual Models of Australia's Estuaries and Coastal Waterways: Applications for Coastal Resource Management, Geoscience Australia Record 2003/09. 2003.

[37] Marohasy, J. \& Abbot, J. Deconstructing the native fish strategy for Australia's Murray Darling catchment, pp. 339-349. River Basin Management VII, ed. C. A. Brebbia, WIT Transactions on Ecology and the Environment, Volume 172, WIT Press, 2013.

[38] Marohasy, J. Mulloway, not carp, belong in the Murray River's estuary, On Line Opinion, 2013,

http://www.onlineopinion.com.au/view.asp?article $=15345$ 